\title{
What women want: the importance of qualitative approaches in evaluating work with women offenders ${ }^{i}$
}

Authors: Carol Hedderman, Clare Gunby and Nicola Shelton

Affiliation: Carol Hedderman and Nicola Shelton, University of Leicester Clare Gunby, Liverpool John Moores University

Address for correspondence

Carol Hedderman

Department of Criminology

University of Leicester

154 New Walk

Leicester LE1 7QA

Tel: 01162523948

Email: ch140@le.ac.uk

Key words

Women Offenders, Methods, Desistance, Outcome Evaluation

\footnotetext{
'This article is based on interviews carried out as part of an early assessment of 'Together Women' commissioned by the Ministry of Justice. This evaluation was designed and undertaken by Carol Hedderman, Clive Hollin and Emma Palmer. Clare Gunby, Nicola Shelton and Melody Askari conducted interviews with service users, staff and stakeholders as part of this study. Loraine Gelsthorpe provided help and guidance on a consultancy basis. We gratefully acknowledge the contribution our colleagues made to the work on which this article is based. We would also like to thank the anonymous reviewers appointed by Criminology and Criminal Justice for their constructive and helpful feedback. Carol Hedderman gratefully acknowledges the period of study leave granted by the University of Leicester.
} 
Biographical Note

CAROL HEDDERMAN is Professor of Criminology at the University of Leicester. Her research interests include evaluating interventions which promote desistance; the development of reconviction scales and other approaches to assessing 'effectiveness'; and the treatment of women at different stages of the criminal justice system.

CLARE GUNBY is a PhD researcher within the Centre for Public Health at Liverpool John Moores University. Her PhD is investigating the role of alcohol intoxication in rape. Formerly she was a Research Associate at the University of Leicester working on the evaluation of prison and community based offending interventions.

NICOLA SHELTON is a Criminology Teaching Fellow at the University of Leicester. Her research interests include the aims, structure and effectiveness of community penalties; offenders' attitudes towards community penalties and custodial sentences; women's motivation to offend and their experiences within the criminal justice process; and desistance processes.. 
What women want: the importance of qualitative approaches in evaluating work with women offenders

\section{Abstract}

In 2004 the government in England and Wales published a new policy on responding to women who offend. The aims were to reduce women's involvement in crime and to divert them from prison. The 'Together Women' project was funded under this policy initiative to demonstrate how services for women offenders should be provided in the community. The first stage of the associated evaluation included interviews with Together Women's clients as their feedback was seen as important in helping to develop effective services and as an early indicator of impact. However, the final assessment of impact relies on a quantitative assessment based on project files and criminal records data. The only interviews to be conducted will focus on asking sentencers about whether they use Together Women to divert women from custody.

This article draws on interviews conducted with Together Women clients in the project's development phase to argue that outcome evaluations which rely exclusively or mainly on information in project databases and criminal records may not capture key elements which make an intervention 'work'. Neglecting service users' insights may lead to under-estimating resource needs, unrealistic target setting, and the eventual abandonment of promising ideas in favour of the next 'new' magic bullet. 
What women want: the importance of qualitative approaches in evaluating work with women offenders

By the late 1990s concerns about women offenders in England and Wales had crystallised around two themes: the belief that women were becoming more like men in terms of the rate and nature of their offending; and that, even with such changes, the steep and continuing rise in the female prison population was neither explicable nor justified. Evidence for the former assumption is equivocal; evidence for the latter assumption is much stronger and clearer (see, for example, Gelsthorpe and Morris, 2002; Hedderman, 2004a). Nevertheless, the incoming Labour government in 1997 took no explicit action to reduce the use of custody for women during its first term. It was not until mid-way through its second term that it published a comprehensive policy on women offenders.

The Women's Offending Reduction Programme Action Plan (Home Office, 2004) began with an uncompromising statement of what many researchers working in the field understood so well:

Statistics show that the courts have been using custody more frequently for women over the last few years, even though the nature and seriousness of their offending has not, on the whole, been getting worse. ...The evidence suggests that courts are imposing more severe sentences on women for less serious offences. (Home Office, 2004:3)

Its aims were also generally welcomed:

Its purpose is to reduce women's offending and the number of women in custody, by providing a better tailored and more appropriate response to the particular factors which have an impact on why women offend. The intention is not to give women offenders preferential treatment but to achieve equality of treatment and access to provision. (Home Office, 2004:5) 
Given the acknowledgement that women's offending was not a large or worsening problem, the reference to reducing offending may seem a little unnecessary, but this was an essential nod towards being 'tough on crime' in a document which was otherwise heavily focused on addressing the 'social exclusion'1 needs of women who had offended in the community. Also, it was reasonable to assume that, given so many of the women who do offend are involved in property crime, tackling issues such as poverty and unemployment would, at least in the longer term, help to reduce offending.

The approach was described as seeking to embed a consideration of the needs of women in existing systems and approaches. Initially, this meant no new resources were being made available to secure delivery. However, just over $£ 9$ million was eventually found to support the 'Together Women' project at five sites in the North of England for three years. These began operating between late 2006 and early 2007 . The project was intended to demonstrate 'how a multi-agency approach in the community could address women's complex needs more effectively' (Ministry of Justice, 2008:5) with the aims of reducing the reoffending of existing offenders and preventing those described as being 'at risk' of offending from becoming involved in crime. The project was also expected to divert women from prosecution and from prison by providing criminal justice practitioners with suitable community alternatives.

Although promoted as a 'demonstration' project, only a little information on it has so far emerged from the Ministry of Justice (Hedderman et al., 2008). Now that the three-year demonstration period has ended, an outcome evaluation has been commissioned. This involves a small number of interviews with sentencers about whether they diverted women from custody into Together Women. Otherwise, the evaluation is assessing impact by measuring reconviction rates and examining project files to measure changes in factors such as substance misuse, mental health and employment. The outcome evaluation will not include an up-to-date assessment of the service user's perspective. 
A number of commentators such as Hollin (2008) and Raynor (2008) have pointed out the dangers of government-funded evaluations being forced to adopt too narrow a range of measures to evaluate community interventions. Drawing on interviews conducted with women who made use of Together Women's services during its first year of operation, this article argues that an up-to-date and detailed appreciation of service users' perspectives is essential if the Together Women model is to be properly understood. This is particularly important if Together Women is to be used as a model for work with women who offend as Corston (2007) recommended. It is equally important in understanding why some interventions do not yield anticipated outcomes.

\section{The Together Women model}

The Together Women approach sought to incorporate best practice lessons derived from the experiences of long-standing schemes for women such as the Asha Centre (Rumgay, 2004a) and the 218 Centre (Loucks et al., 2006). This included ensuring that the level and range of services a woman received was determined by an assessment of individual need; and that the resulting support plan was holistic. It was regarded as essential that service users should be involved in the design and review of such plans, rather than being treated as passive service recipients.

Although the exact range of support available to women varied a little between the five Together Women centres, it included training and interventions on issues such as parenting, managing mental health and life skills. Each centre arranged for service providers to hold surgeries covering a range of issues (e.g. accessing benefits or housing) but also functioned as a drop-in centre, where women could access activities such as reading groups and complementary therapies. Where suitable provision existed, Together Women attempted to tap into it; where there was a gap, the centres commissioned another provider or delivered a service in-house. For example, where waiting lists for local counselling services involved a wait of several months, some Together Women centres provided counselling on site which 
could be accessed in days or weeks. Early feedback from other service providers in the five areas shows that Together Women was seen as a welcome development which filled important gaps. This was also apparent in the way these other service providers referred to, and accepted referrals from, Together Women (see Hedderman et al., 2008).

It was anticipated that three-quarters of Together Women's clients would have some current involvement in the criminal justice system (ranging from arrest through to post-release supervision). The remaining quarter was expected to be 'at risk' of offending, although what constituted 'at risk' was not defined clearly at the outset in policy statements or project initiation documents. 'At risk' was operationalised at the five centres to mean that assistance would be provided to any woman who was beset by two or more social exclusion factors such as mental illness, substance abuse, homelessness, and sexual or domestic victimisations. In practice, many of those 'at risk' had previous experience of the criminal justice system.

\section{The importance of interviewing women in an evaluative study}

Interviewing women is probably the most common approach adopted by those trying to understand the causes of women's offending and their experiences in the criminal justice system (see, for example, recent edited volumes by Heidensohn (2006) and Sheehan et al. (2007)). Their stories, as Heidensohn (1985:14) explains, 'make the connection between private troubles and public issues'. Initially such stories were seen by some as acting as a corrective to the focus of mainstream criminology in which women's offending was either 'neglected or distorted' (Heidensohn and Gelsthorpe, 2007:383). Perhaps today, rather than focusing exclusively on women's offending and their roles in the criminal justice process, more of us share Cain's (1990) view that it is only by considering women's (and men's) broader lives, and the way in which gender is constructed, that a meaningful understanding of their experiences can be attained. 
Those writing from a desistance perspective are equally concerned to develop methodologies which recognise that persistence and desistance are processes rather than static, binary states. Indeed, they criticise the interviews conducted in longitudinal criminal career studies for favouring the repetition of closed questions and for representing fluid social processes as discrete 'events', because this leads to assumptions about causality based on the sequence in which such 'events' occur (Farrall, 2003). Researchers from a desistance perspective prefer to conduct repeated qualitative interviews with those who have offended and those who supervise them. In these interviews open-ended questions about changes in experiences and feelings are used to throw light on how and why change - or stability - occurs. While probation and prison interventions may be examined as part of this sort of inquiry, usually such studies are not intended to specifically assess and measure the value of such interventions in isolation. Indeed, the point of much desistance work is to examine the way a range of factors interact, showing how superficially similar situations may operate differently at the individual level, because of the way such experiences are perceived and acted upon (Farrall, 2002; McNeill, 2006; McNeill, 2009). However, Farrall (2003:169-170) notes that 'Further light could be shed upon the processes and outcomes of probation supervision by asking probationers what they had learnt while on probation, whether they felt it had helped them to avoid further trouble or alleviated particular problems that they had faced'. They also recognise the lack of desistance studies which focus on women, and the resulting uncertainty about the significance of the term 'desistance' for women (e.g. Farrall et al., 2007).

Advocates and critics alike acknowledge that the evidence base for 'what works' is mainly derived from studies of males, and that gender specific interventions must be developed for women (e.g. Loucks et al., 2006; Hollin and Palmer, 2006a). There is less agreement, however, on what such interventions might look like (e.g. Bloom and Covington, 1998; Blanchette and Brown, 2006; Hollin and Palmer, 2006b).

The majority of current probation programmes, with their emphasis on a cognitive behavioural approach, are heavily influenced by psychology, as is 
the approach to their evaluation favoured by the Home Office/Ministry of Justice (Hedderman, 2004b). Qualitative interviews are often seen by psychologists who evaluate work with offenders as particularly helpful at an early stage, when the objectives and delivery of a programme are still under development, to scope a range of outcome criteria and assist in the final choice against which success is to be judged and 'when legal, anthropological, ethical and economic issues have to be assessed' (Lösel, 2007:154). While recognising that there is also value in employing qualitative techniques at a later stage (for example, in describing how programme delivery varies by site), Lösel (2007) concludes that the ultimate objective is to use that information to implement a better controlled random control trial (RCT). However, other psychologists such as Hollin (2008) argue against taking such a doctrinaire approach, because, of course 'RCTs do not answer other important questions such as why an intervention works or which parts have the most effect' (Hedderman, 2004b: 187). In the case of Together Women, at least part of the answer to those questions involves knowing about the problems those accessing the service faced, what they thought about the way Together Women operated, and the value of the assistance it provided.

\section{Listening to Together Women service users}

Two rounds of interviews were conducted with those referred to Together Women during its first year of operation. Forty-three service users were interviewed shortly after their first contact with Together Women (June to July 2007). Together Women key workers played a gate-keeping role in selecting clients for interview in so far as they checked that a woman was happy to talk to us before we approached her; and that she was not too vulnerable to be interviewed. Many Together Women clients had mental health issues (particularly depression) and several had previously attempted suicide, so this was a necessary safeguard. As we were interviewing women at a very early stage in their time with Together Women, it is unlikely that staff sought to select those who would be most positive about the help they had received. 
We sought interviews with two-thirds of the 43 women three months after the first interview, hoping to contact at least one third of the original sample. At least three attempts were made to contact each woman, either directly (they had all given their permission for us to do this at first interview) or through Together Women. We succeeded in contacting and re-interviewing our minimum target of 14 women (between November and December 2007), all of whom were continuing to use Together Women services. ${ }^{2}$ The most common reason for not achieving a second interview was that women had disengaged with the service and were untraceable.

The fact that we were unable to contact those who had disengaged may mean that those women who were re-interviewed may have been more positively disposed to Together Women. However, it would be a mistake to picture those who were re-interviewed as a group who had maintained unbroken contact. Indeed, if the window for conducting a second interview had opened a little earlier, or closed a little later, we might easily have failed to re-interview some of them and succeeded in re-interviewing some of those we missed. For example, on re-interviewing 'Pat' the interviewer reported:

Things have not gone well for the interviewee since the first interview, and she is 'back where I started', insofar as she has returned to her chaotic lifestyle and unstable living arrangements, and is drinking again. She has been 'thrown out' of the homeless hostel because of this, as the drink causes her to become verbally aggressive. However, the [domestic violence] project that she had attended at Together Women has taught her how to handle her relationship and her partner's violence towards her in a better way. Unfortunately, this has not stopped the violence completely and there was a short period when she did not come to Together Women as she was ashamed of the bruises on her face. She was persuaded by a friend, who she met through Together Women, to come back to the centre and she has been attending regularly ever since. 
Pat's story also suggests that those we re-interviewed had no less serious or less complex problems than those who had become uncontactable.

As the interviews we conducted were part of a formative evaluation of Together Women, it was essential that certain topics were covered in every interview, although it was necessary to ask only a few 'closed-ended' questions. Instead the three (female) interviewers were trained to use a schedule which outlined the themes to be covered. The interviewers were encouraged not to stick rigidly to the way most of the questions were worded, but to ensure that they covered all the core themes while making the interview as comfortable and informal as possible for the service user. Each interview also ended with the interviewer encouraging the service user to make any additional comments about their experience of Together Women which had not emerged earlier in the interview. The results of the interviews were collated using the thematic headings from the interview schedule, and then read and reread by one senior member of the research team. The resulting report was then checked by other members of the team to ensure that it was an accurate representation of the views expressed.

\section{What do Together Women clients say about the difficulties they face?}

In reviewing the range of problems Together Women clients described in interview, four clear findings emerge. The first is that Together Women was picking up the target group it had set itself. Clients rarely described having only one or two problems and their problems tended to be severe, interrelated, complex and often long-standing. Three examples may help to illustrate this:

Nora: I'm 39, I have three children, I am an ex drug user and an ex alcoholic, my eldest is 19 so she has her own flat, and my 16 year old is at home... Because I'm not too confident at coming out...I used to have to go to the shops with people and stuff...l couldn't go out on my own though I am getting much better... 
Nina: I'm single, I'm 40, l've got mental health problems, and I'm a paranoid schizophrenic. l've got five children, they are in foster care at the moment. I was on drugs but now l'm drugs free, that's why my children were put into foster care. I've been off drugs for a year and a half now and I'm pleased with that. I'm working on getting my children back, my eldest daughter is coming out of foster care in October so working on that. I have an autistic little boy and he's hard work... I'm having a bit of a bad relationship with my partner .... because he's been knocking me about...every time she [the Together Women key worker] phones me that's the first thing she says, 'how's he treating you?'

In the case of Irene the interviewer recorded:

Irene was 24 years old at the time she was first interviewed. She was living with her partner. Her two children, aged four and two years, were living with their grandmother. This is a social services arrangement, as the interviewee was 'using drugs when I had them'. However, she is in regular contact with them. She is not currently in any employment, education or training as she is 'on the sick with post traumatic stress disorder, due a lot to what happened when I were younger'. She appeared to have a severe nervous condition and was in a perpetual state of agitation throughout the interview, moving her head and limbs, which made it a great effort for her to speak: 'Me mental health, which I suffer from post traumatic stress disorder, split borderline personality disorder, depression, anxiety and self-harm - and that's due to me abuse when I were younger. So, they think they're gonna help me get in touch with, erm, psychotherapy for my depression, to see if it can help. You know, with the abuse and my drink problem, 'cause l've got a problem with heroin and crack, and I'm on a prescription medication which is methadone to help me come off that, but I'm still using on top, a little bit, sometimes, so that I can cope better. And they're helping me with my basic Maths and English skills, and stuff. 
The second point, which these cases also illustrate, is that while the same range of factors, such as mental health and addiction issues, were to be found across cases, their exact manifestation and how they are perceived by the client varied from one to another.

The third noteworthy finding to emerge about the characteristics of those who had offended is that, although they gave different reasons for offending (a moment of weakness, a character flaw, feeding an addiction, a lack of choice), none of them described offending as enjoyable or mentioned the 'thrill' of offending. The reasons for this are unclear and the finding may well be specific to the women who accessed Together Women. However, if it is more generally true, it raises doubts about the value for women of some of the accredited programmes running in prisons and in the community where tackling thrill seeking and impulsivity are key ingredients. While the National Offender Management Service guidance on dealing with women offenders notes (2008:33) 'The relative low levels of women in the criminal justice system suggests that pro-criminal attitudes are less prevalent amongst women..., it does not acknowledge that there may be qualitative differences in the attitudes of women who do offend.

Finally, the most common issues mentioned by Together Women clients were their lack of confidence and self-esteem. These may not seem the most serious issues faced by service users when so many of them were also dealing with substance abuse, homelessness, poverty and violence. However, because they did not believe in the possibility of change or that they were worth helping, they neither sought help to deal with other issues nor stuck with the help that was offered to them.

The importance of empowering women to promote desistence has been recognised by a number of commentators (e.g. Bloom and Covington, 1998; Pollack, 2004; Gelsthorpe et al., 2007). However, the way in which a lack of self-esteem promotes offending and inhibits desistance may not be fully understood by those developing offending behaviour programmes, who regard it as a 'responsivity' issue (e.g. Hollin and Palmer, 2006b). In other 
words it is understood to affect the style of delivery rather than the substance of the assistance provided. However, if a lack of self-confidence is an offending-related need for women in its own right, those working with women who have offended need to do more than address a lack of confidence as a delivery style issue. They may also need to consider how this permeates and interacts with other aspects of a woman's life to increase her risk of offending by limiting the development of both human and social capital.

\section{What do clients value about Together Women?}

Key workers who see service users as people not cases

A common theme to emerge from interviews was that key workers were perceived as being personally interested in their clients, with a long term commitment to seeing them through, rather than seeing them as 'cases' to be resolved as quickly as possible. This was certainly connected to the client's active participation in creating and reviewing their own support plans, but it emerged most strongly in interviews where women recounted incidents in which they came in to Together Women or phoned in because something had happened (examples ranged from being evicted or having children taken into care, to feeling suicidal or being tempted to begin taking drugs again). They described being surprised and grateful that a Together Women worker was not only prepared to see them or talk to them straightaway but to spend as long as was necessary with them and then follow-up several times subsequently to ensure that the client was coping. For example, Nina explained:

I sometimes think about going back to drugs... but when I do I come here instead...it's a good replacement...sometimes I phone my key worker and ask her to come and fetch me and I explain why and she says well at least you got something good out of the project...its very friendly, the girls are very friendly. They should have done this ages ago...I would have come off the drugs years ago...I really hope they keep this place going because we do need it...it's a good place. 
The relationship of trust is fragile and important. For the professional concerned, failing to deliver on a promise may be a single slip, but this is unlikely to be the way a client perceives it, as Vera noted:

I was promised all kinds by my key worker in the hostel, l'll get you help with counselling, l'll get you help with drinking issues but nothing, ten weeks down the line I was still where I was, if not maybe getting worse. I'd just had enough one day ... and the lady I see here, who is now my key worker, she's brilliant; she gets things done there and then.... I was a bit hesitant because I thought 'Can I trust you?' Because I get promised all the time and I keep getting let down, but she sticks to her word. That's why l've got my appointment on Wednesday to go and see this accommodation... everything l've asked them they've been able to help me with, and anything I needed, if they can help me, they'll help me. They don't just say l'll do it and never get round to it, they do actually do what they say....The way they come through. If they say they're going to do something, they'll do it. That's the main thing, the most positive thing about it...

The feeling that Together Women workers were genuinely interested in their welfare also meant that this was how its clients perceived the visits, telephone calls and reminders they received both to prompt them to attend Together Women and to remind them of missed appointments. This was true even among those on court orders who might have perceived such reminders as 'enforcement'. For example, when one woman (Wendy) returned after not attending for some time, she found:

It's nice to know that somebody thinks about you and that, you know, there is somebody there to turn to. ... I thought it'd be like another authority. I thought it'd be like, erm, police, probation, social services kind of, you know, making these rules, setting down, I must do this, and I must do that, and it's not been anything like that...obviously, they're not gonna put up with my bloomin' nonsense, and all that sort of 
thing - but they just tell me what I should be doing, really, and then basically they leave it to me whether I take it on board, or phone me and try and encourage me, 'Have you done that?', you know. But it's not like, you know, social services, the authorities, police and things like that.

Another women (Mel) explained:

I went to anger management but then I wasn't so good at coming so I stopped. I got two letters from them writing and saying I haven't been for a few days asking if I'm alright, they said if there's any problems get in touch with them, that they're looking forward to hearing from you. They wrote twice in four days, I live on my own so that was good of them wasn't it? Someone does care. I was thrilled to bits when I opened the letter....

The feeling that key workers were interested in them as individuals had a range of benefits. Some clients described how the feeling that they 'owed' their key worker led them to attend when they would otherwise not have done. Others described how when they thought about taking drugs again they resisted because they felt they would be letting their key worker down. One woman described overcoming her fear of going to a job interview because she felt grateful to her key worker for getting her the opportunity and felt it would be ungrateful not to attend. These findings accord with those from previous research (e.g. Trotter, 2007) and reviews of practice (e.g. Bloom and Covington, 1998; Gelsthorpe et al., 2007) that suggest the quality of the relationship these service users develop with their key workers may be a key factor in promoting desistance, particularly for women. At the very least, this insight is important in understanding how to combat women's lower completion rates (see Martin et al., 2009). 
At her second interview, Vera also commented on the way Together Women staff helped without patronising or judging. 'The staff here, as soon as you come in they offer you a cup of tea which is nice. They don't judge you, they take you for who you are.' This sense of being respected and not judged was something which came out in many interviews. Importantly, these comments concerned the way all members of staff treated service users. From the moment a client came through the door they were made to feel welcome by reception staff. This atmosphere was also fostered between clients. Service users who had been involved in Together Women for some time seemed to enjoy taking newcomers under their wing. This appeared to have benefits for both parties in that the newcomer immediately felt included and the 'oldtimer' gained confidence and pride in showing the newcomer the ropes:

It's given me more confidence. I find I can speak to people more 'cause, like, new people are coming in and l'll talk to them, and l'll show them where, [key worker] will say 'go show them where so-and-so is' and I'll do that, whereas before I would've just sat there. (Orla)

One of the reasons that Together Women offers services for women who are offenders and those who are at risk is evidence that this practice improves the quality and availability of the services available to women offenders and the mixed environment brings the offenders into greater contact with pro-social peers. It also reduces the likelihood of stigma (Rumgay 2004a; 2004b). The last of these advantages was commented on by some of the women interviewed who said they did not feel embarrassed about telling their friends and families about attending Together Women, although some claimed to have successfully hidden the fact that they were on probation even from close family members. 


\section{The women-only environment}

For some women, the women-only environment was an essential feature which enabled them to feel safe. It was a deciding factor in the decision to make use of Together Women in some cases. For example, Kerry, who had been raped and subject to domestic violence by her partner, explained:

Well, I prefer it to be like that because of the experiences that I've been through. Because, at the moment, I can be alright with some males, like, because there's male key workers at the hostel and that. I'm fine with them, but, like, some people on the outside, sort of thing, it's [pause] I find it very uncomfortable.

Reflecting on her experience of the centre after three months, Kerry added:

After the experience l've been through if there are men around and things like that, it's nice to know you're in a safe place, especially when you're talking about emotional things and things like that.

Another woman (Tina) contrasted Together Women favourably with her experience of attending her probation appointments:

... when I went there, there's a lot of men there and I go in on my own, always well-dressed and I have men looking at me and I feel really uncomfortable. I used to hate waiting in that room.... So when I came here it was like, oh great, I don't have to worry about all of that. In Probation everyone is 'F-ing and Blinding' and they're all smoking and it was just horrible. They're all arguing with the staff and it's a really horrible experience; and I remember one time I had to take my daughter because she was off school and I was with my old Probation Officer and I'm going to have to bring her and I said 'Am I alright to bring her in on my appointment?' and she said 'Oh yes, don't leave her out there because you don't know who's in here' and that really worried me... 
In fact, probation officers arranged to meet women who were on court orders at some Together Women centres for these reasons, and because it helped to reinforce the idea of providing a holistic approach.

Although being a women-only centre was not important for all the women interviewed, no one expressed a preference for attending mixed facilities and they also recognised that it was important for other service users, if not for themselves. The women-only environment also engendered a feeling of connection with other service users. However different their lives were in other respects, they all shared the experience of being women.

\section{The quality of the environment}

Each of the centres was either purpose built or had been refurbished to a high standard before accepting Together Women clients. The colour schemes were bright and the furniture was new, modern and comfortable. This was mentioned by virtually every woman we interviewed. For some it was a rare indicator that they were seen as worth spending resources on. Many expressed pride in the way 'their' centre looked. This sense of 'ownership' was encouraged by staff and further strengthened by the centres which all displayed the artwork the women created during sessions at the centres. It may be that the good physical environment created and maintained in the centres encouraged a sense of respect and community feeling which encouraged women to feel more valued and more optimistic about the possibility of change.

\section{Was being involved in Together Women helpful and likely to reduce offending?}

Most of those referred to Together Women as offenders, who were interviewed shortly after their first contact, were very optimistic about their chances of avoiding further offending. While this may have been justified, the views of those who were still in contact with Together Women after at least 
three months were canvassed to see whether they were equally certain of success. All of those interviewed at this point, who had previously offended, expressed an unequivocal desire to stop offending and, where these were issues, to tackle their problems with drink and drugs. However, only one woman was entirely confident that she would succeed without Together Women. She was unusual in other respects too in that, while she was on probation for a serious assault, she had never offended before. She also had no other social exclusion issues aside from losing her job during her court case. Having previously worked full-time, she had gained another relatively well-paid job during her time with Together Women.

The women who seemed least confident about avoiding further offending continued to portray their lives as being shaped by the actions of others and life's vicissitudes. These women also tended to be those with long-standing substance abuse and mental health problems. For them, every day was described as a struggle. They not only had to battle addiction or illness but the difficulties such conditions generated or exacerbated, such as being evicted for being drunk, being unable to work, mounting debt, losing custody of their children, self-harm and suicidal thoughts. For example, Pat whose continuing difficulties were described earlier explained:

Yeah. I've been in trouble with the law again, actually, but that was through me alcohol and through me partner, but I would've possibly been in more trouble had I not had this place. And possibly [pause] done things, possibly [pause] tried to harm meself. You know, if I didn't have this place to come to, I would've just totally gave up, I think, a couple of times, you know. But instead, l've got myself up and come here instead, and it's helped me.

Given her reference to domestic violence and suicidal feelings, the fact that Pat did not see avoiding further offending as an objective in itself is perhaps understandable. In her case, it might be argued that offending was a consequence, or even a side-effect, of her other problems. This was certainly how she saw it and how she was dealing with it. 
Interestingly, those who had made the least obvious progress or were least confident about their chance of stopping offending were among the most grateful for the help they had received from Together Women. Orla, who described herself as an alcoholic who currently had her drinking under control, said she spent four full days a week at the centre. When asked how she thought this would affect her future behaviour, she explained: 'I don't know if it's made a difference to my future but it has made a big difference in my life.' Several others described Together Women as being the one place to which they had been able to turn after other agencies, family and friends had given up on them. For example, Nina concluded:

With my past, because nobody was helping me and I needed someone to talk to because I was feeling suicidal so they guessed the mentor would help me and it is helping me.... If didn't have this place then yes I think I would because l'd just be bored and have nowhere to go. So this place is a God-send really.

Most women described a much more mixed picture of how successful they had been to date in avoiding relapse and reoffending; and how sanguine they were about the future. Three aspects of the support they received from Together Women seemed to be associated with how likely women judged the prospect of desistance. First, those who saw themselves as least likely to reoffend described the way Together Women had made them feel selfconfident and in control. For example, Kerry concluded:

I know I wouldn't go out and commit another offence..... It's mainly from what l've gone through and also the confidence building course because that has helped me to know how to stand up to another man like him.

Penny was also fairly sure she would not reoffend: 
Yes, it's because I'm not lonely, and having somebody there to talk to. I wouldn't dream of it.... and you can tell by me now from last time a difference, so you know it's doing something good.

Second, Together Women's holistic approach and individualised support plans were often mentioned as being a key factor which made success more likely. For example, Chris noted:

I've detoxed to the point where l'm not physically dependent upon it anymore and I don't feel that I'm emotionally dependent upon it so l've been managing it on my own but just in case, l'd like to continue to come here and keep in touch with my key worker .... l've got a lot of debt and my key worker has just referred me to someone in [name of town] who gives free debt counselling advice so that's another reason to keep coming because there are lots of other areas that I feel she can help me with....Yes, as I say I'm managing on my own fairly well but I do still feel I need somebody there just in case..... Counselling is going to hopefully help me come to terms with my son's death which I hadn't. They helped me to stop drinking and to sort things out with my daughter. In the beginning, like you said about a mountain, if I woke up in the middle of the night I didn't know what to think about first. I'd worry about my daughter, I might think about my son, l'd worry about getting a job, what sort of job would I do or I might worry because I'd got a job but not gone to it. I didn't open my post, there was no point looking at my debt because I didn't know where to start with it. Whereas now that I'm getting things sorted out a little bit at a time...

Third, as the interviews with Penny and Chris demonstrate, continuing support from Together Women or, at least, the chance to come back to Together Women, was seen as important in maintaining success.

Saying that some women found the prospect of desistance unlikely is not the same as saying that they were following the zig-zag path Burnett (2004) identified in relation to some male offenders which is marked by hesitance 
and vacillation. The women we interviewed did not express any ambivalence in their desire to stop offending; some simply doubted whether this was a realistic aspiration because of the range and depth of factors which they saw as working against such change. For most of those interviewed after three months, their progress can be characterised as 'taking two steps forward and one step back' (Hedderman et al., 2008:13). Given that Together Women (successfully) sought out women with at least two major social exclusion problems, this is actually a positive finding after only three months of support.

\section{Conclusion}

As most convicted offenders are male, it is unsurprising that most interventions devised to reduce offending have been designed for, and tested on, them. The very fact that the Corston Review (2007) was commissioned and that Together Women was funded suggests that it is now generally understood that 'what works' for men may not be suitable for women. Views on how poorly these interventions fit the offending-related needs of women vary partly because of the a priori assumptions of the commentator and partly because of the relative lack of evidence about women's offending-related needs and 'what works' in addressing them. Together Women was modelled on the best available evidence about what works with socially excluded women and women offenders. This evidence base was derived mainly from small-scale, qualitative assessments of projects which have often been run by enthusiastic volunteers on shoestring budgets. In this context, the decision to attempt to assess Together Women's impact quantitatively is welcome. However, relying exclusively on quantitative results is potentially dangerous.

The first two reasons that a purely quantitative study is ill-advised are practical ones. First, while the number of cases referred to Together Women (nearly 3,000 by early December 2008) is large enough to sustain simple analyses (e.g. women did or did not reoffend), it may not sustain further important breakdowns because not all of those referred were assessed. Second, record-keeping concerning the help women had received and outcomes 
varied in nature and quality between the different Together Women centres. But these practical problems are common (see, for example, Hollin et al., 2004) and, while the studies they affect may not yield clear-cut answers, they do provide useful ones.

There is a more important difficulty to be addressed in assessing the impact of Together Women however, and that is the question of who it is for and what it is designed to achieve. While Together Women is badged as a programme for offenders or those 'at risk' of offending, in practice at a local level this means any woman with serious social exclusion issues. The question of whether Together Women is a programme for offenders who happen to be women or women who happen to be offenders is not a matter of semantics; it goes straight to the heart of the main question a quantitative analysis would be designed to address. Is stopping reoffending the main goal of the programme (especially given some of its clients have not offended before)? And if this is not the main criterion against which success is to be judged, what is?

Even if the numbers permitted it, assessing Together Women's impact on specific individual needs, when the essence of its approach is holistic, is also inherently problematic. For example, if a woman is homeless, has mental health issues and abuses alcohol is found a place in a hostel, should this case be judged a success overall? What else might need to change - and by how much - before such a designation was justified?

Listening to Together Women service users shows that, before they can benefit from practical help with issues such as substance abuse, they need to believe that they can change. Their lack of self-belief and their view of life as happening to them, rather than being actively lived, is the most striking feature of the interviews we conducted. It may not be possible to justify the cost of activities such as needle-point and collage-making quantitatively by demonstrating impact, but understanding the role such activities play in boosting confidence and self-belief is vital if they are not to be dismissed as inessential or even frivolous when budgets tighten. While confidence can be 
assessed on quantitative scales and even measured over time, this has the effect of turning a process into a series of events. This approach is unlikely to pick up the way confidence can ebb and flow as other elements in an individual's life change, or why change occurs. Similarly, even assuming the quality of the relationship a woman developed with her key worker could be scaled quantitatively, this would provide snapshots of one relationship but may miss out on those with other staff which may be equally important.

Even after three months of contact with Together Women, few women felt that they could manage without their support. The fact that these women talked about their growing confidence and feelings of control suggests that Together Women has not fostered feelings of dependence and that this need is real. It is difficult to see how a purely quantitative outcome study would pick up on this factor, yet it has major implications for how Together Women staff manage their caseloads, how quickly quantifiable outcomes should be assessed, and how well and how long interventions like Together Women should be funded.

There are two potential, equally unfortunate possible futures if Together Women is assessed simplistically, using quantitative measures which do not precisely fit its objectives, which miss out key elements in the process, and which fail to recognise how long change may take. The first is that Together Women is judged to be a failure so other similar projects are not funded and the hunt for the next magic bullet begins. The second is that Together Women is judged to be a success, but without clearly understanding what the essential elements are. In this case failure will take longer as pale imitations will be rolled out which fail to replicate the initial results, because they lack these vital ingredients, and the search for the next 'magic' bullet, though delayed, will begin all over again. 


\section{References}

Blanchette, K. and Brown, S. L. (2006) The assessment and treatment of women offenders: An integrative perspective. Chichester: Wiley.

Bloom, B. and Covington, S. (1998) Gender-Specific Programming for Female Offenders: What is it and Why is it Important? Paper presented at the 50th Annual Meeting of the American Society of Criminology, Washington, D.C, November.

Burnett, R. (2004) 'To re-offend or not to re-offend? The ambivalence of convicted property offenders', in S. Maruna and R. Immarigeon (eds.), After Crime and Punishment: Pathways to Offender Reintegration. Cullompton, Devon: Willan, pages 152-180.

Cain, M. (1990) 'Towards transgression: new directions in feminist criminology', International Journal of the Sociology of Law, 18:1-18.

Carlen P. (2002) 'New discourses of justification and reform for women's imprisonment in England' in P. Carlen (ed.) Women and Punishment. Collumpton, Devon: Willan, pages 220-236.

Corston, J. (2007) The Corston Report: a review of women with particular vulnerabilities in the criminal justice system. London: Home Office.

Farrall, S. (2002) Rethinking What Works with Offenders: Probation, Social Context and Desistance from Crime. Cullompton, Devon: Willan.

Farrall, S. (2003) 'J' Accuse: Probation Evaluation-Research Epistemologies: Part One: The Critique', Criminal Justice, 3(2):161-161-179. 
Farrall, S., Mawby, R. and Worrall, A. (2007) 'Prolific/persistent offenders and desistance, in L.R. Gelsthorpe and R. Morgan (eds.) The Probation Handbook of Probation. Cullompton, Devon: Willan, pp 352-380.

Gelsthorpe, L. and Morris, A. (2002) 'Women's Imprisonment in England and Wales: A Penal Paradox', Criminal Justice, 2(3): 277-301.

Gelsthorpe, L., Sharpe, G. and Roberts, J. (2007) Provision for Women Offenders in the Community. London: Fawcett Commission.

Hedderman, C. (2004a) 'Why are more women being sentenced to custody?', in G. Mclvor. (ed.) Women who Offend. London: Jessica Kingsley, pages 82-96.

Hedderman, C. (2004b) Testing times: how the policy and practice environment shaped the creation of the What Works evidence-base, VISTA, 8(3): 182-8.

Hedderman, C., Palmer, E. and Hollin, C. (2008) Implementing services for women offenders and those 'at risk' of offending: action research with Together Women, Ministry of Justice Research Series 12/08. London: Ministry of Justice.

Heidensohn, F. (1985) Women and Crime. London: Macmillan.

Heidensohn, F. (ed.) (2006) Gender and Justice: new concepts and approaches. Cullompton, Devon: Willan.

Heidensohn, F. and Gelsthorpe. L. (2007) 'Gender and Crime', in M. Maguire, R. Morgan. and R. Reiner. (eds.) The Oxford Handbook of Criminology, $4^{\text {th }}$ edition. Oxford: Oxford University Press, pages, 381-420.

Hollin, C.R. (2008) 'Evaluating offending behaviour programmes: Does only randomization glister?' Criminology and Criminal Justice, 8 (1): 89-106. 
Hollin, C.R., Palmer, E.J., McGuire, J., Hounsome, J., Hatcher, R., Bilby, C. and Clark, C. (2004) Pathfinder Programmes in the Probation Service: A Retrospective Analysis, Home Office Online Report 66/04. http://www.homeoffice.gov.uk/rds/onlinepubs1.html

Hollin, C. R. and Palmer, E. J. (2006a) 'Criminogenic need and women offenders: A critique of the literature', Legal and Criminological Psychology, 11(2), 179-195.

Hollin, C. R. and Palmer, E. J. (2006b) 'Offending behaviour programmes: Controversies and resolutions', in C. R. Hollin and E. J. Palmer (Eds.), Offending behaviour programmes: Development, application, and controversies. Chichester: John Wiley \& Sons, 247-278.

Home Office (2004) Women's Offending Reduction Programme (WORP) Action Plan. London: Home Office.

Lösel, F. (2007) Doing evaluation research in criminology, in R. D. King and E. Wincup (Eds.), Doing Research on Crime and Justice. Collumpton, Devon: Willan, 141-170.

Loucks, N., Malloch, M., Mclvor, G. and Gelsthorpe, L. (2006) Evaluation of the 218 Centre. Edinburgh: Scottish Executive.

Martin, J., Kautt, P. and Gelsthorpe, L. (2009) 'What works for Women? A comparison of Community-based Offending Programme Completion', British Journal of Criminology, 49(6), 879-899.

McNeill, F. (2006) 'A desistance paradigm for offender management', Criminology and Criminal Justice, 6(1): 39-62. 
McNeill, F. (2009) Towards Effective Practice in Offender Supervision. Glasgow: The Scottish Centre for Criminal Justice.

Ministry of Justice (2008) National Service Framework for Women Offenders. London: Ministry of Justice.

National Offender Management Service (2008) The Offender Management Guide to Working with Women Offenders. London: Ministry of Justice.

Pollack, S. (2004). 'Anti-oppressive Social Work Practice with Women in Prison: Discursive Reconstructions and Alternative Practices', British Journal of Social Work, 34(5), 693-707.

Raynor, P. (2008) 'Community penalties and Home Office research: On the way back to 'nothing works'?', Criminology and Criminal Justice, 8(1): 73-87.

Rumgay, J. (2004a) The Asha Centre: Report of an Evaluation. London: London School of Economics.

Rumgay, J. (2004b) 'Living with paradox: community supervision of women offenders,' in G. Mclvor (ed.) Women who Offend. London: Jessica Kingsley,pages 99-125

Sheehan, R., Mclvor, G. and Trotter, C (ed.) (2007) What Works with Women Offenders, Cullompton, Devon: Willan.

Trotter, C. (2007) 'Parole and Probation', in R. Sheehan, G. Mclvor and C. Trotter (eds.) What Works with Women Offenders, Cullompton, Devon: Willan.

\footnotetext{
${ }^{1}$ We share Carlen's (2002) concern that the term 'social exclusion' is sometimes used to draw attention away from race and class, but it is used here as a collective term to include
} 
these as well as poverty and debt, lack of education, unemployment mental health, a history of abuse etc.

${ }^{2} \mathrm{~A}$ further twelve were interviewed after at least three month's contact with Together Women but their experiences are excluded from this discussion as it is not possible to consider how their circumstances and attitudes changed over time. 